\title{
Fractionation and evaluation of proteins in roots of Echinacea purpurea (L.) Moench
}

\author{
GABRIELE BALCIUNAITE ${ }^{1}$ \\ JOVITA JUODSNUKYTE ${ }^{1}$ \\ ARUNAS SAVICKAS ${ }^{3}$ \\ ONA RAGAZINSKIENE ${ }^{4}$ \\ LUKA SIATKUTE ${ }^{1}$ \\ GITANA ZVIRBLYTE 2 \\ EDITA MISTINIENE ${ }^{2}$ \\ NIJOLE SAVICKIENE ${ }^{1^{*}}$ \\ ${ }^{1}$ Department of Pharmacognosy \\ Lithuanian University of Health Sciences \\ Kaunas, Lithuania \\ ${ }^{2}$ Institute of Biotechnology \\ Vilnius University, Vilnius, Lithuania \\ ${ }^{3}$ Department of Social Pharmacy and \\ Drug Technology, Lithuanian University \\ of Health Sciences, Kaunas, Lithuania \\ ${ }^{4}$ Kaunas Botanical Garden of Vytautas \\ Magnus University Kaunas, Lithuania
}

Accepted July 14, 2015

\begin{abstract}
Echinacea purpurea (L.) Moench, a member of the Asteraceae family, is a plant rich in flavonoids, essential oils, phenolic compounds, saponins, polysaccharides and glycoproteins. The aim of the study was to evaluate the protein content in dried roots of Echinacea purpurea (L.) Moench after homogenization of roots with liquid nitrogen, extraction in 0.01 mol L ${ }^{-1}$ phosphate-buffered saline (PBS) and purification followed by fractionation of proteins using gel filtration chromatography. Total concentration of proteins was measured using the Bradford method, and evaluation of the molecular mass of proteins was accomplished by applying the SDS-PAGE gel electrophoresis. The Bradford assay revealed that the highest concentration of proteins in fractions collected after gel filtration chomatography was 4.66$6.07 \mathrm{mg} \mathrm{mL}^{-1}$. Glycoproteins, alkamides and polysaccharides in roots of Echinacea purpurea (L.) Moench are chemical compounds that are responsible for their immunomodulatory properties. However, information about the difference of protein contents in fresh and dried roots of E. purpurea is insufficient.
\end{abstract}

Keywords: Echinacea purpurea (L.) Moench, proteins, gel filtration chromatography, SDS-PAGE

Echinacea purpurea (L.) Moench (Asteraceae) is a herb well known for its usage in medicine. It is rich in phenolic compounds, including caffeic acid derivatives (0.6-2.1\%) - mainly cichoric, caftaric, chlorogenic and isochlorogenic acids and flavonoids (e.g., rutoside, quercetin and kaempferol). Alkamides (0.01-0.04 \%) mostly isobutylamides of C11-C16 straight-chain fatty acids with olefinic or acetylenic bonds are also characteristic constituents of the roots of E. purpurea. Polysaccharides (inulin, arabinogalactan), proteins and glycoproteins extracted from the roots of E. purpurea exhibit anti-inflammatory activity by stimulating the immune cells. Other constituents, including the saturated pyrrolizidinetype alkaloids, such as tussilagine andisotussilagine, polyacetylene derivates, and up to $0.2 \%$ of essential oils (e.g., containing caryophyllene or humulene, limonene and camphene) have also been isolated from the roots of E. purpurea (1). Even though plant proteins

\footnotetext{
* Correspondence; e-mail: savickienenijole@takas.lt
} 
are currently being intensively studied for their antiproliferative (2), antibacterial (3), antioxidant (4) and anti-inflammatory (5) activities, there is a lack of information about such compounds in the roots of E. purpurea. In this study, proteins extracted from the dried roots of E. purpurea were evaluated according to their molecular size and their molecular mass, and their content in the roots was determined.

\section{EXPERIMENTAL}

\section{Chemicals and materials}

Ammonium sulfate $(99.0 \%)$ and $\varepsilon$-amino-capronic acid (> $99.0 \%)$ were supplied by Carl Roth $\mathrm{GmbH}+\mathrm{Co}$ KG (Germany). Polyvinylpyrrolidone (PVPP), benzamidine $(99.0 \%)$, and $0.01 \mathrm{~mol} \mathrm{~L}^{-1}$ phosphate-buffered saline (PBS), pH 7.2, consisted of 10.9 g sodium phosphate monobasic (Sigma-Aldrich, USA), anhydrous ( $\geq 99.0 \%$ ) (Sigma-Aldrich), $3.2 \mathrm{~g}$ of sodium phosphate dibasic, anhydrous ( $\geq 99.0 \%$ ) (Sigma-Aldrich), and 90.0 g of sodium chloride (Sigma-Aldrich), all dissolved in $1000 \mathrm{~mL}$ of distilled water.

Whatman ${ }^{\circledR}$ regenerated cellulose membrane filters, pore size $0.45 \mu \mathrm{m}$, were purchased from Sigma-Aldrich. Centriprep YM-3 centrifugal filters obtained from EMD Millipore (USA) were used in the desalting and concentration procedure of the E. purpurea protein sample. The phosphate buffer (PB) Centipur ${ }^{\circledR}, \mathrm{pH} 7.0$, was obtained from Merck (Germany). Bovine serum albumin (>99.0 \%) used as a standard substance in the Bradford protein assay, acrylamide/bis-acrylamide (30\%), sodium dodecyl sulphate (98.5\%) and Bradford reagent (Coomassie Brilliant Blue G-250) were purchased from Sigma-Aldrich.

The PageRuler Prestained Protein Ladder used as a standard mixture in SDS-PAGE, 10 to $180 \mathrm{kDa}$, was purchased from the Thermo Scientific ${ }^{\mathrm{TM}}$ Protein Biology Products (Lithuania). The Thermo Scientific Pierce Silver Stain Kit was obtained from Fisher Scientific (USA). The tris-buffer $\left(0.25 \mathrm{~mol} \mathrm{~L}^{-1}\right.$ Tris, $1.92 \mathrm{~mol} \mathrm{~L}^{-1}$ glycine, $\mathrm{pH}$ approx. 8.3) was purchased from Sigma-Aldrich.

\section{Apparatus}

AnIKA M20 grinder was obtained from IKA ${ }^{\circledR}$-Werke GmbH \& Co. KG (Germany). Gel filtration chromatography was carried out using the ÄKTA Purifier 100 system Plus supplied by GE Healthcare Life Sciences (Sweden). The UNICORN 5.31 software [GE Healthcare Life Sciences (USA)] was employed to collect and analyze the gel filtration chromatography data. The separation of proteins was performed using Superdex 200 10/300 GL column $(13 \mu \mathrm{m}$ particles, $300 \times 10 \mathrm{~mm}$ ) obtained from GE Healthcare Life Sciences (USA).

An Infinite M200 spectrophotometer obtained from TECAN (Germany) was used to measure the absorbance of samples in order to determine their protein concentration. A thermostat Techne Dri-Block (R) Model DB-2D was purchased from Techne (UK).

\section{Preparation and storage of plant material}

Dried roots $(300 \mathrm{~g})$ of 3-year-old E. purpurea plants were purchased from the Botanical Garden of Vytautas Magnus University, Kaunas, Lithuania, in September 2013. The specimens were taxonomically identified at the Department of Pharmacognosy of the Lithua- 
nian University of Health Sciences, Kaunas, Lithuania. Dried roots were stored in a dark place. This plant material was exposed to the temperature of $20 \pm 1{ }^{\circ} \mathrm{C}$ and a humiditycontrolled environment ( $50 \pm 5 \%$ ) until required for extraction.

\section{Protein extraction and purification}

The roots of the plant were ground with an IKA M20 grinder just before extraction. The plant material (40 g) was homogenized with liquid nitrogen in a mortar. The homogeneous material was extracted in $200 \mathrm{~mL}$ of PBS with $5 \mathrm{mmol} \mathrm{L}^{-1}$ of benzamidine, $5 \mathrm{mmol}$ $\mathrm{L}^{-1}$ of $\varepsilon$-amino-capronic acid, and $2 \%$ of PVPP for $12 \mathrm{~h}$ at the temperature of $4-5{ }^{\circ} \mathrm{C}$. The extract was filtered through a cellulose membrane filter and centrifuged at 1,500 rpm for $30 \mathrm{~min}$ at $4-5{ }^{\circ} \mathrm{C}$. Purification of proteins was followed by the salting out procedure. The filtrate $(150 \mathrm{~mL})$ was saturated (6). After $24 \mathrm{~h}$ of constant stirring, saturated solution was centrifuged at 15,000 rpm for $30 \mathrm{~min}$. The resulting precipitate was dissolved in $1 \mathrm{~mL}$ of PBS solution and kept at $4{ }^{\circ} \mathrm{C}$.

The precipitate was re-suspended and dialyzed for $48 \mathrm{~h}$ in dialysis membrane tubing with $0.22-\mu \mathrm{m}$ pores against three changes of PBS. The peptide solution was desalted, removing ammonium sulfate, and concentrated to $1.5 \mathrm{~mL}$ with Centriprep YM-3 centrifugal filters (7).

\section{Gel filtration chromatography}

Gel filtration chromatography was used to separate the protein mixture into fractions according to size (8). The procedure was performed with the ÄKTA Purifier 100 Plussystem, using the Superdex 200 10/300 GL column, applying isocratic elution with PB. The procedure was carried out at constant temperature of $+4{ }^{\circ} \mathrm{C}$. The column matrix was a spherical composite of cross-linked agarose and dextran. The column was previously equilibrated with $50 \mathrm{~mL}$ of distilled water. Afterwards, the system was pre-equilibrated and eluated with $\mathrm{PB}$. The flow rate was $0.5 \mathrm{~mL} \mathrm{~min}^{-1}$ and the maximum pressure over the column was 1.4 MPa.

Prior to the injection into the system, the protein sample $(1.5 \mathrm{~mL})$ was centrifuged at $10000 \mathrm{rpm}$ for $15 \mathrm{~min}$ at the temperature of $+4{ }^{\circ} \mathrm{C}$. After that, the protein sample was manually injected into the system with a $500-\mu \mathrm{L}$ injection loop. Each $0.5 \mathrm{~mL}$ fraction was collected in tube. Proteins were detected by monitoring their UV absorbance: proteins with aromatic amino acids were tested at $280 \mathrm{~nm}$ and peptide bonds at $215 \mathrm{~nm}$. Following that, the protein amounts and molecular masses were examined in the collected fractions. Negative control (PB) was treated in the same manner (10).

\section{Bradford microassay}

Protein quantity was measured by applying the Bradford method (9) using $0.125,0.25$, $0.5,1.0,1.5$, and $2 \mathrm{mg} \mathrm{mL}^{-1}$ of the bovine serum albumin (BSA) protein standard. Each prediluted standard or sample $(120 \mu \mathrm{L})$ was placed into a separate microplate well and mixed with $120 \mu \mathrm{L}$ of Coomasie Brilliant Blue Dye G250. The absorbance of both standard and sample solutions was measured at $595 \mathrm{~nm}$. The concentration of an unknown protein in 
the sample was determined by using the equation $y=0.0205 x+0.0105\left(R^{2}=0.9955\right)$ defining the calibration curve plot (10).

\section{SDS-PAGE gel electrophoresis}

The samples were prepared by mixing proteins with an electrophoresis sample buffer and heating the mixture at $95{ }^{\circ} \mathrm{C}$ for $5 \mathrm{~min}$. Sodium dodecyl sulfate-polyacrylamide gel electrophoresis (SDS-PAGE) was carried out in a slab mini-gel apparatus, using $15 \%$ polyacrylamide as the separating gel, and $4 \%$ polyacrylamide as the stacking gel. During the analysis, $30 \mu \mathrm{L}$ of each sample was added into the wells of the gel slab, and $5 \mu \mathrm{L}$ of the PageRuler Prestained Protein Ladder was used as the standard mixture. Power conditions for gel electrophoresis were $200 \mathrm{~V}$ and $25 \mathrm{~mA}$, and the run time was $90 \mathrm{~min}$. After SDSPAGE, the gels were fixed and stained with silver nitrate. Molecular masses were estimated by comparison with the migration rates of the standard protein.

\section{RESULTS AND DISCUSSION}

\section{Fractionation by gel filtration chromatography}

Proteins from the roots of E. purpurea were separated into 80 fractions during gel filtration chromatography. Peaks were obtained in fractions No. 29, 30, 36, 40, 42-43, 48, 54, 58-59, 62-63, and 65-66. Fractions No. 29, 30, 36, 37, 40, 42, 48, 62, and 65 were chosen for the Bradford microassay because they showed the highest peaks.

\section{Protein microassay}

The amount of proteins in the fractions was determined as mentioned previously. The concentrations are shown in Table I. The highest amount of proteins was in fractions No. 29, 30, 36, and 37, and hence these fractions were chosen for SDS-PAGE gel electrophoresis.

Table I. Concentration of proteins in fractions when applying the Bradford method

\begin{tabular}{cc}
\hline Fraction No. & Concentration $\left(\mu \mathrm{g} \mathrm{mL}^{-1}\right)$ \\
\hline 29 & $6.068 \pm 0.020$ \\
30 & $5.083 \pm 0.016$ \\
36 & $4.663 \pm 0.046$ \\
37 & $5.956 \pm 0.036$ \\
40 & $4.01 \pm 0.011$ \\
42 & $4.288 \pm 0.006$ \\
48 & $2.044 \pm 0.025$ \\
62 & $2.302 \pm 0.019$ \\
65 & $1.259 \pm 0.003$
\end{tabular}




\section{SDS-PAGE gel electrophoresis}

SDS-PAGE electrophoresis showed separated protein fractions No. 29, 30, 36, and 37. According to the PageRuler Prestained Protein Ladder, the standard molecular mass of the proteins in fraction No. 29 was 14, 30, 35, and $120 \mathrm{kDa}$, and in fraction No. 30-14, 25, 30, 35, and $120 \mathrm{kDa}$. The molecular mass of the protein in fractions No. 36 and 37 was $36 \mathrm{kDa}$ (Fig. 1). Glycoproteins with a molecular mass of 17, 21, 30 and $120 \mathrm{kDa}$ were isolated from the roots of E. purpurea in previous studies (11). It was estimated that glycoproteins with lower molecular mass contained approximately $3 \%$ of protein. Aspartate, glycine, glutamate, and alanine are the major amino acids of the protein moiety while arabinose, galactose, and glucosamine are the main sugars (12).

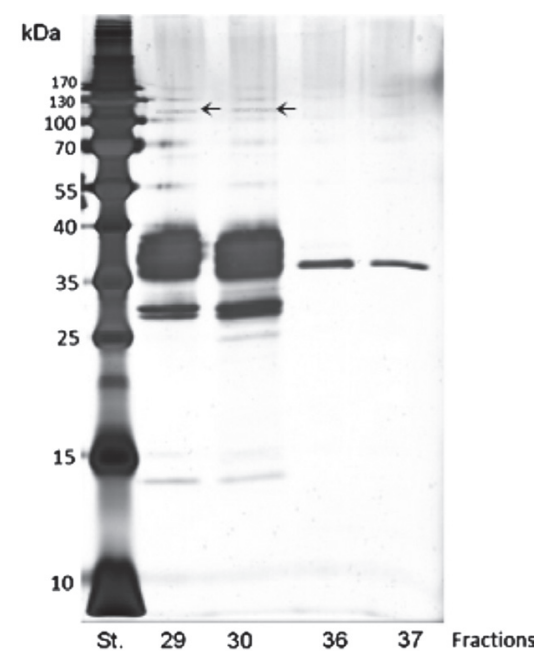

Fig. 1. Molecular mass of proteins in separated fractions of E. purpurea (arrows show 120 kDa sized protein bands).

The experimental data revealed that the pressed juice of E. purpurea contained $120 \mathrm{kDa}$ arabinogalactan protein (AGP) known to be responsible for the immunomodulatory properties of the plant (13). Previous studies have shown that the polysaccharide moiety of AGP is $90 \%$ and mainly consists of arabinose and galactose residues. Glutamine, asparagine, hydroxyproline, serine, threonine and alanine are the dominant amino acids of the protein moiety (14). According to our investigations, the bands of $120 \mathrm{kDa}$ in fractions No. 29 and 30 were pale and blurred, which means that there was only a very small amount of $120 \mathrm{kDa}$ sized protein. This suggests that fresh plant material contained more AGP sized protein than dried material (12). The presence of AGP in dry plant material still remains to be evaluated.

Two bands of $30 \mathrm{kDa}$ in fractions No. 29 and 30 were identified, which indicated the presence of two polypeptides that shared the same amino acid sequence. Such polypeptides are usually isoenzymes that perform similar functions, but each of them is differently specialized for a specific tissue and/or purpose (14). 
The aim of our experiment was to determine the protein size in dried E. purpurea roots and to compare our results with those presented in the literature. Our pilot experiments hypothesize that proteins in dried roots of E. purpurea could be isomers or glycosylated protein forms, judging by the SDS-PAGE image. Nevertheless, structural, quantitative and qualitative investigations of protein and glycoprotein, content should be carried out in the future.

\section{CONCLUSIONS}

Our results showed a trace of AGP-sized proteins in dried plant material, suggesting that the drying process affected protein content in the roots when compared to the fresh juice of E. purpurea. Therefore, a more thorough characterization of small-sized protein content in dry root material is required in order to determine its chemical structure and biological activity.

Acknowledgments. - The authors gratefully acknowledge the support through a Grant (No. TAPLB-12-006) of the Lithuanian Foundation for Research and Studies.

\section{REFERENCES}

1. D. C. Hell, J. Barnes, L. Anderson, S. Gibbons and J. D. Phillipson, Echinacea species (Echinacea angustifolia (DC.) Hell., Echinacea pallida (Nutt.) Nutt., Echinacea purpurea (L.) Moench): a review of their chemistry, pharmacology and clinical properties, J. Pharm. Pharmacol. 57 (2005) 929-954; DOI: $10.1211 / 0022357056127$.

2. Q. Zheng, D. Qiu, X. Liu, L. Zhang, S. Cai and X. Zhang, Antiproliferative effect of Dendrobium catenatum Lindley polypeptides against human liver, gastric and breast cancer cell lines, Food Funct. 5 (2015) 1489-1495; DOI: 10.1039/C5FO00060B.

3. J. J. Dong, F. Wu, X. Ye, C. F. Sun, Y. Y. Tian, M. X. Lu, R. Zhang and Z. H. Chen, $\beta$-Defensin in Nile tilapia (Oreochromis niloticus): Sequence, tissue expression, and anti-bacterial activity of synthetic peptides, Gene 566 (2015) 23-31; DOI: 10.1016/j.gene.2015.04.025.

4. I. Arcan and A. Yemenicioglu, Antioxidant activity of protein extracts from heat-treated or thermally processed chickpeas and white beans, Food Chem. 103 (2007) 301-312; DOI: 10.1016/j.foodchem.2006.07.050.

5. P. Abreu, S. Matthew, T. Gonzalez, D. Costa, M. A. Segundo and E. Fernandes, Anti-inflammatory and antioxidant activity of a medicinal tincture from Pedilanthus tithymaloides, Life Sci. 78 (2006) 1578-1585; DOI: 10.1016/j.lfs.2005.07.037.

6. R. J. Simpson, Protocol: Bulk precipitation of proteins by ammonium sulfate, Cold Spring Harb. Protoc. 2006; DOI: 10.1101/pdb.prot4308.

7. A. Gupta and R. S. Sandhu, A new high molecular weight agglutinin from garlic (Allium sativum), Molec. Cell. Cell. Bioch. 166 (1997) 1-9; DOI: 10.1023/A:1006827921151.

8. H. C. Silva, A. U. Bari, B. A. Rocha, K. S. Nascimento, E. L. Ponte, A. F. Pires, P. Delatorre, E. H. Teixeira, H. Debray, A. M. Assreuy, C. S. Nagano and B. S. Cavada, Purification and primary structure of a mannose/glucose-binding lectin from Parkia biglobosa Jacq. seeds with antinociceptive and anti-inflammatory properties, J. Mol. Recogn. 26 (2013) 470-478; DOI: 10.1002/jmr.2289.

9. M. M. Bradford, A rapid and sensitive method for the quantitation of microgram quantities of protein utilizing the principle of protein-dye binding, Anal. Biochem. 72 (1976) 248-254; DOI: 10.1016/0003-2697(76)90527-3. 
10. K. Hyung-Keun, L. Hyuk-Min, O. Kyong-Hwa, Y. Hyo-Jin, J. Ji-Seon and K. Sook-Kyung, Interpretation of protein quantitation using the Bradford assay: Comparison with two calculation models, Anal. Biochem. 434 (2013) 178-180; DOI: 10.1016/j.ab.2012.10.045.

11. S. Thude and B. Classen, High molecular weight constituents from roots of Echinacea pallida: An arabinogalactan-protein and an arabinan, Phytochemistry 66 (2005) 1026-1032; DOI: 10.1016/j.phytochem.2005.02.028

12. J. B. Harborne and C. A. Williams, Phytochemistry of the Genus Echinacea, in Echinacea: The genus Echinacea (Ed. S. C. Miller), CRC Press, Boca Raton 2004, pp. 61-77.

13. R. B. Volk, W. Blaschek and B. Classen, Characterization of an arabinogalactan protein from the pressed juice of Echinacea purpurea: investigations into the type of linkage between the protein and polysaccharide moieties, J. Nat. Med. 61 (2007) 397-401; DOI: 10.1007/s11418-007-0174-3.

14. A. Bossy, W. Blaschek and B. Classen, Characterization and immunolocalization of arabinogalactan-proteins in roots of Echinacea purpurea, Planta Med. 75 (2009) 1526-1533; DOI: 10.1055/ s-00291185801. 